\title{
Armillaria root rot threatens Cameroon's Penja pepper (Piper nigrum L.)
}

\author{
Sandrine Petchayo Tigang ${ }^{1,2}$ (D) James Michel Tchotet Tchoumi ${ }^{3}$. Jolanda Roux ${ }^{4}$ - Julienne Nguefack ${ }^{1}$. \\ Aime Didier Begoude Boyogueno ${ }^{2} \cdot$ Michael Mbenoun $^{2} \cdot$ Crescence Virginie Mfegue $^{2} \cdot$ Salomon Nyassé $^{2}$. \\ Michel Ndoumbé Nkeng ${ }^{2,5} \cdot$ Gerben Martijn ten Hoopen ${ }^{2,6}$
}

Received: 15 November 2019 / Accepted: 27 April 2020 / Published online: 27 May 2020

(C) Sociedade Brasileira de Fitopatologia 2020

\begin{abstract}
Penja pepper (Piper nigrum) produced in Cameroon has long been recognized for its exceptional organoleptic quality. The pepper vine is grown using a support tree (Spondias mombin) in Cameroon. A root disease is associated with plant deaths in both plants. The disease symptoms are characterized by collar cracking and gummosis and the disease was tentatively identified as Armillaria root rot. In this work the extent of the problem was characterized by surveying 35 farms in Cameroon. Samples were taken from diseased support trees and pepper vines. Support trees exhibiting typical symptoms were found in approximately one third of the surveyed farms. In these farms, disease incidence and Pepper vine mortality ranged from 1.3 to $50 \%$ and 1.2 to $87.7 \%$, respectively. Analysis of the ribosomal internal transcribed spacer region (ITS) locus suggested that the isolates collected from S. mombin and P. nigrum are most likely, which is a first for both hosts, represented by Armillaria camerunensis (Henn.) Volk \& Burdsall, a fungus previously associated with declining cacao trees in Cameroon. Given the increasing demand for Penja pepper and the great damaging potential of this root rot, research on management strategies should be prioritized.
\end{abstract}

Keywords Armillaria camerunensis $\cdot$ Disease incidence $\cdot$ Molecular identification $\cdot$ Slow decline $\cdot$ Support tree

Sandrine Petchayo Tigang

ptsandy2000@gmail.com

1 Department of Biochemistry, Faculty of Sciences, University of Yaoundé I, P.O. box 812 Yaoundé, Cameroon

2 Institute for Agricultural Research for Development (IRAD), P.O. box 2067 Yaoundé, Cameroon

3 Department of Biochemistry, Genetics and Microbiology, Forestry and Agricultural Biotechnology Institute (FABI), Faculty of Natural and Agricultural Sciences, University of Pretoria, Pretoria 0028, South Africa

4 Department of Plant and Soil Sciences, Forestry and Agricultural Biotechnology Institute (FABI), Faculty of Natural and Agricultural Sciences, University of Pretoria, Pretoria 0028, South Africa

5 Centre Africain de Recherches sur Bananiers et Plantains (CARBAP), B.P. 832, DoualaBonanjo, Cameroon

6 CIRAD, UPR Bioagresseurs, St. Augustine, Trinidad and Tobago. Bioagresseurs, Univ. Montpellier, CIRAD, Montpellier, France

\section{Introduction}

The pepper vine (Piper nigrum) is a tropical perennial crop, native to India, which belongs to the Piperaceae family (Ravindran 2000). It is cultivated in several countries including Brazil, Indonesia and Vietnam which are the world's largest producers of pepper (Faostat 2017). According to the International Pepper Community (IPC 2017) pepper is the "King of spices" since it is the most consumed and marketed spice in the world. Besides its popular use in cuisine and seasoning, the spice has shown medicinal attributes. Pepper can help relieve viral respiratory ailments such as flu and colds, as well as digestive problems such as constipation, flatulence and colic (Meghwal and Goswami 2012; Ahmad et al. 2012).

Black pepper was introduced to Cameroon in the 1930s and although the exact origin of first introduction is unknown, the first vines were introduced into Cameroon by the Germans, and later by French Planters and the Cameroon Development Corporation (CDC). They brought in cultivars from Cambodia, the Democratic Republic of Congo (DRC) (at the time the Belgian Congo) and India. It is the descendants 
of this miscellany of cultivars that are now grown in Cameroon.

The pepper produced in Cameroon has long been recognized by connoisseurs to be among the world's best, owing to its outstanding organoleptic attributes. This exceptional quality has earned Penja black pepper the first sub-Saharan protected geographical indication (GI) label in September 2013 by the African Intellectual Property Organization (OAPI), further boosting its reputation. Although Cameroonian production remains marginal $(<0.02 \%$ of global production) (Faostat 2017), it has increased over the past few years by over a factor of 10, as pepper attracts increasing interest from local farmers, stimulated by the GI label for Penja pepper and a concomitant price increase from $\$ 4.2$ before the GI to $\$ 23.6$ USD per $\mathrm{kg}$ in 2015. Prices oscillated between \$20.20 and \$23.6 US dollars between 2016 and 2018.

As is the case for any intensively propagated crop, diseases and pests are a major constraint limiting black pepper productivity. Numerous pests and diseases have been reported to affect pepper vines; some of which are well known to cause severe losses, e.g. Phytophthora foot rot caused by Phytophthora capsici Leonian, (Ravindran 2000; Truong et al. 2008), blackberry disease caused by Colletotrichum species (Keuh 1990), and slow decline (or yellow disease) which can result from various pathogens and complexes of biotic and abiotic stressors (Ramana and Santhosh 2000). In Cameroon, as cultivation of pepper is intensifying so is the pressure of phytosanitary problems. In recent years especially, there has been a growing concern among farmers about the losses associated with diseases, which in some cases have resulted in up to $50 \%$ mortality in certain pepper plantations. The "Plantations du Haut Penja" (PHP) organization, the biggest pepper producer in Cameroon, saw its production area reduced from 40 to 21 ha because of disease pressure (Mbodiam 2019). According to preliminary assessments, these losses are most likely associated with a range of biotic and abiotic stressors that remain to be resolved (Petchayo et al. 2015).

In Cameroon, a disease affects the pepper's support tree, Spondias mombin L (hog plum), a native of the Americas and West-Indies. The support tree is critical for pepper cultivation as it provides a structure for optimum growth and productivity of pepper plants (Ravindran 2000). The disease affecting $S$. mombin is characterized by collar cracking, gummosis and the presence of white fungal mycelial fans beneath the bark, which are all typical symptoms of Armillaria root rot (Fig. 1c, d). A preliminary investigation indicated that like the support tree, the pepper vine was also susceptible to this disease (Petchayo et al. 2015). However, further studies are needed to support the development of effective management strategies. The aim of this study was therefore two-fold: 1) to elucidate the cause of the disease by means of DNA sequence analyses and; 2) to assess the incidence of root rot in Penja Pepper farms across the certified geographic area using field surveys.

\section{Materials and methods}

\section{Field observations and sample collection}

The Penja pepper production basin lies within the fourth agroecological zone, as defined by the Institute of Agricultural Research for Development (IRAD) of Cameroon. This region straddles the Littoral and South-West administrative regions of the country. It features a tropical rain forest as native vegetation cover and a subequatorial climate type, characterized by $2500-4000 \mathrm{~mm}$ annual rainfall, $22-29^{\circ} \mathrm{C}$ mean temperatures and $61-90 \%$ relative humidity.

Field observations for root rot and sample collection were carried out in May-June 2016, on a total of 35 farms, selected from the database of the association of Penja pepper producers (Penja Pepper Geographical Indication Group, IGPP for its abbreviation in French) and based on farmer's indications whether the disease was present or not. Farms were distributed over the districts of Penja-Njombe $\left(n=14\right.$; N4 ${ }^{\circ} 38.799^{\prime}$ E9 ${ }^{\circ}$ 40. 331'), Loum $\left(n=7 ; \mathrm{N}^{\circ} 42.140^{\prime} \mathrm{E} 9^{\circ} 46.318^{\prime}\right)$ in the Littoral region, and Tombel $\left(n=13 ; \mathrm{N}^{\circ} 39.685^{\prime}\right.$ E9 36. $\left.853^{\prime}\right)$ in the South-West region. Each plantation was surveyed to determine the prevalence of the disease. Two transects, perpendicular to each other, were laid out in the center of each pepper field. Each transect was $28 \mathrm{~m}$ long and included three rows of pepper plants planted together with support trees (S. mombin) at $2 \times 2 \mathrm{~m}$ spacing. Thus, a maximum of 81 pepper vines and support trees were examined and a sanitary status was assigned to vines and support trees separately, either healthy, diseased, or dead/absent (absence of a support tree or vine was assumed to be due to the death of the plant). Potential differences per district and plantation age group (3$6,7-10$ and $>10$ yrs. of age) were analyzed using arcsintransformed percentage disease incidence data for support trees and mortality incidence for vine trees with the appropriate generalized linear model in XLSTAT v. 2019.4.1.

Eleven symptomatic vine/support tree combinations were randomly sampled in one farm per district. Infected samples were collected from roots, collar and trunk of pepper and support trees (Fig. 1a-f) following a purposive stratified random sampling technique. All samples were placed in paper bags, duly labeled and brought back to the laboratory for further analyses. Additional information regarding age of the plantation, associated crops and previous land use was also collected.

\section{Isolation of pathogen}

Isolation of suspected Armillaria cultures from infected plant materials was performed as described by Tchotet Tchoumi et al. (2017). Small pieces $\left(2-3 \mathrm{~mm}^{3}\right)$ of woody tissue were taken from the advancing edge of lesions and were surface sterilized in $7 \%$ sodium hypochlorite for $90 \mathrm{~s}$, then rinsed twice in sterile distilled water and dried using sterile tissue paper. These 
Fig. 1 Disease symptoms in pepper plantations in the Penja region of Cameroon, (a) support trees (S. mombin) most of which are devoid of pepper vines; (b) a dead pepper wine, reminescent of slow decline; (c) gum exuding from the base of a dying support tree; (d) white mycelial fans underneath the bark of support tree; (e) basal stem cracking of black pepper; (f) white mycelium underneath the root bark of P. nigrum; (g) Morphological characteristics in vitro of Armillaria isolate
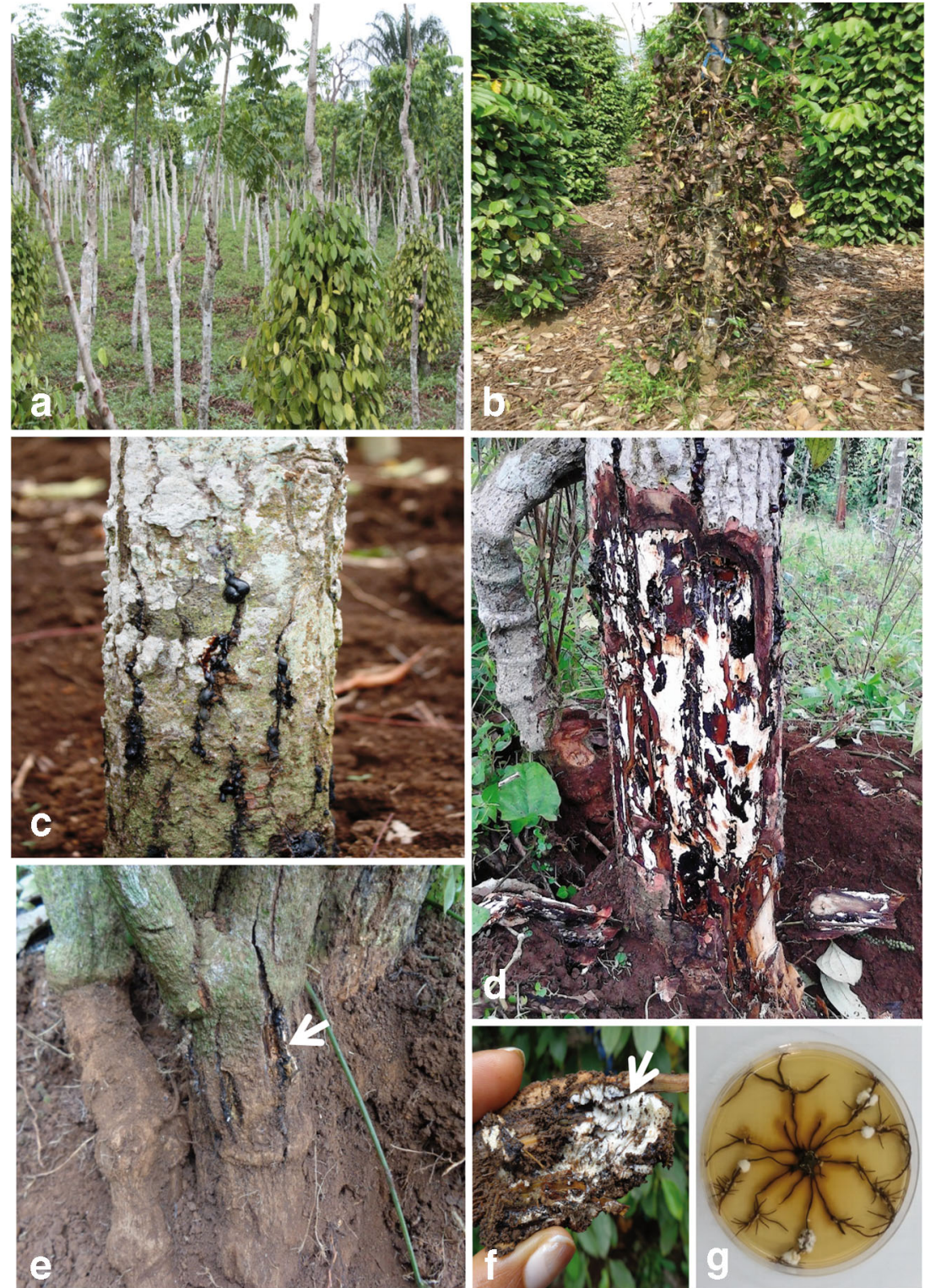

sterilized plant materials were plated onto Basidiomycete selective medium, made up of 2\% Malt Extract Agar (MEA) supplemented with $2 \mathrm{mg} / \mathrm{L}$ benomyl, $2 \mathrm{mg} / \mathrm{L}$ dichloran and $0.01 \mathrm{~g} / \mathrm{L}$ streptomycin sulphate (Worrall 1991). Plates were incubated at ambient temperature $\left(25 \pm 2{ }^{\circ} \mathrm{C}\right)$ in the dark for two weeks, and pure cultures were obtained from these by transferring rhizomorph tips onto new MEA plates, which were also maintained at ambient temperature.

\section{DNA extraction, amplifications and phylogenetic analysis}

Mycelium from pure cultures was harvested, freeze-dried and ground to a fine powder using a cell disruptor machine (Retsch Gmbh, Germany). Genomic DNA was extracted using the CTAB protocol as described by Möller et al. (1992). Prior to amplifications, the initial DNA concentrations were adjusted to $100 \mathrm{ng} / \mu \mathrm{L}$ using a Nanodrop ND-1000 Spectrophotometer (Thermo Fisher Scientific, Wilmington, DE, USA). PCR amplifications targeted the ITS regions (ITS1, ITS2), including the 5.8S subunit of the ribosomal DNA and was done using the primer pair ITS1 (5'-TCCGTAGGTGAACCTGCGG-3') and ITS4 (5'-TCCTCCGCTTATTGATATGC-3') (White et al. 1990). PCR and sequencing reaction mixtures and reaction conditions were the same as outlined in Tchotet Tchoumi et al. (2017). DNA sequencing was done at the sequencing facility of the University of Pretoria. The CLC Main Workbench v.7.6.1 package was used to edit bidirectionalsequencing reads and to assemble contigs. The ITS sequences were subsequently queried against the global fungal DNA sequence database in the GenBank nucleotide database using the NCBI BLASTn search tool (https://blast.ncbi.nlm.nih.gov). A 
dataset of Armillaria ITS sequences was assembled, comprising representatives from the different localities and hosts ( $P$. nigrum and $S$. mombin) targeted by this study, the sequences obtained by Roux et al. (2012) on cacao (Theobromae cacao) in Cameroon, as well as all BLASTn hits in GenBank with $\geq 97 \%$ sequence identity. Sequences representing A. hinnulea were included in the dataset as outgroups (Table 1). The dataset was submitted to multiple sequence alignment with the online program MAFFT (http:// mafft.cbrc.jp/alignment/server/) prior to phylogenetic analysis based on Maximum likelihood (ML) criterion using RaxML (Stamatakis 2006) in raxmlGUI 1.3 (Silvestro and Michalak 2012). The analysis used 10 parallel runs and 1000 bootstrap replications and applied the GTR $+\mathrm{G}$ model of sequence evolution determined as best fit under the Akaike Information Criterion (AIC) using JModeltest v2.1.6 (Darriba et al. 2012; Miller et al. 2010).

\section{Pathogenicity test}

A pathogenicity test was conducted using six-month old Piper nigrum plants obtained from cuttings and kept under natural conditions, and two Armillaria isolates (CMW44956 and CMW45278). Two inoculation methods were used: soil inoculation and artificial wounding modified from Ford et al. (2017).

For the soil inoculation technique four mycelial agar plugs of the same size, overgrown with the respective Armillaria isolates, were mixed with the soil of each pot containing pepper plants. In the wound inoculation study $5 \times 5 \mathrm{~mm}$ agar plugs containing three-week-old mycelium from each isolate were inserted into a wound made on the collar of each plant. A total of seven pepper seedlings per fungal isolate were inoculated for each inoculation technique. Seven plants were inoculated with sterile agar plugs to represent the controls. Plants were maintained for four months, with daily watering. At the beginning and over the course of the experiment, several growth parameters were evaluated, such as number of leaves, max plant length and mortality. At the end of the experiment, plants were collected and leaf and root dry weight data were collected. Changes in plant height and leaf area were determined, as well as lesion length, measured from the center of the inoculation point, between the beginning and end of the experiment. The general health status of the roots was also determined. Treatment effects were evaluated by fitting a one-way Anova model in XLSTAT v.2019.4.1.

\section{Results}

\section{Field observations}

The average plantation age of the 35 surveyed farms was around 8 years ( 3 to 15 years) (Table 2). From a total of
2832 inspected vine/support tree combinations (three support trees were absent), 157 (5.5\%) of the support trees were visibly affected and showed symptoms of collar cracking and gummosis. The percentage of affected support trees ranged from zero to more than $50 \%$ between farms (Table 2). There was no significant effect of districts $(P=0.501)$. In the Tombel district, 7 out of 13 farms $(53.8 \%)$ were affected and disease incidence in affected farms ranged from 1.2 to $22.2 \%$. In the NjombePenja district 3 out of 13 farms (23.1\%) were affected and disease incidence in affected farms ranged from $1.2 \%$ to $50.6 \%$. Finally, in the district of Loum 2 out of 9 farms (22.2\%) showed symptoms with disease incidences of 3.7\% and $45.7 \%$. Some surveyed farms $(n=13)$ had no support trees affected by the disease even though the owners indicated that the disease was present (Table 2). On the surveyed farms for which the farmers had indicated the absence of the disease, the disease was indeed absent. This discrepancy between farmer indications and transect data is partially due to the fact that the transect was laid out in the middle of the plot, where in certain cases indeed no diseased trees were present, although diseased trees were sometimes present outside of the transect area. The transect area was put in the middle of the plot to avoid edge effects for certain other parameters measured.

With regard to the pepper vines, a total of 515 out of 2832 support trees (18.2\%) (Table 2) were devoid of vines. In other words, on average a fifth of any plantation was unproductive. Contrary to "Armillaria" incidence, all farms had a certain level of pepper vine mortality, however, once again there were no marked differences between the three districts $(P=0.123)$. Pepper vine mortality was often associated with yellowing of the vine before subsequent desiccation. Unfortunately, the etiology of yellowing disease in Penja pepper remains to be resolved. Biotic stressors such as nematodes, Phytophthora and Pythium species as well as Fusarium solani (f. sp. piperis) might be involved (Cardoso and Albuquerque 1979; Ramana et al. 1987; Anandaraj et al. 1996; Shahnazi et al. 2012). Although nematodes, Pythium/Phytopythium spp. and Fusarium, have been found in these pepper plantations (data not shown), it has not been possible to unequivocally link these to the slow decline of pepper vines. Correct identification of these organisms, like for Armillaria here, will be a first step. Recent advances allowing the correct determination of e.g. the presence of Fusarium solani f. sp. piperis (Costa et al. 2017) will be useful in this respect.

For both support tree and pepper vine, disease was not related to plantation age ( $P=0.208, P=0.958$, respectively). This might indicate that the problems/pathogen(s) afflicting support trees and/or pepper vines were already present at the time of plantation establishment or arrived very shortly after.

\section{Pathogen identification}

All sampled diseased plants presented similar symptoms, such as cracking of the bark and wood (Fig. 1c, e) and presence of 
Table 1 Isolates used in the phylogenetic analysis

\begin{tabular}{|c|c|c|c|c|c|}
\hline Species & Strain* & Host & Geographical origin & $\begin{array}{l}\text { GenBank accession } \\
\text { numbers (ITS) }\end{array}$ & Reference \\
\hline Armillaria camerunensis & TH 9926 & Dead wood & Cameroon & KU170951 & Koch et al. 2017 \\
\hline A. camerunensis & TH DJA 91 & Gilbertiodendron dewevrei & Cameroon & KU170952 & Koch et al. 2017 \\
\hline Armillaria sp. & CMW34125 & T. cacao & Cameroon (B) & MG254549 & Roux et al. 2012 \\
\hline Armillaria sp. & CMW36819 & T. cacao & Cameroon $(\mathrm{N})$ & MG254551 & Roux et al. 2012 \\
\hline Armillaria sp. & CMW36820 & T. cacao & Cameroon $(\mathrm{N})$ & MG254552 & Roux et al. 2012 \\
\hline Armillaria sp. & CMW36821 & T. cacao & Cameroon (K) & MG254553 & Roux et al. 2012 \\
\hline Armillaria sp. & CMW43766 & Spondias mombin & Cameroon (P) & MG182003 & This study \\
\hline Armillaria sp. & CMW44921 & S. mombin & Cameroon (P) & MG182004 & This study \\
\hline Armillaria sp. & CMW44922 & S. mombin & Cameroon (P) & MG182005 & This study \\
\hline Armillaria sp. & CMW44923 & S. mombin & Cameroon (P) & MG182006 & This study \\
\hline Armillaria sp. & CMW44924 & S. mombin & Cameroon (P) & MG182007 & This study \\
\hline Armillaria sp. & CMW44927 & S. mombin & Cameroon (L) & MG182008 & This study \\
\hline Armillaria sp. & CMW44956 & Piper nigrum & Cameroon (Njombe) & MG182009 & This study \\
\hline Armillaria sp. & CMW45278 & Piper nigrum & Cameroon (P) & MG182010 & This study \\
\hline Armillaria sp. & CMW45281 & S. mombin & Cameroon (Njombe) & MG182011 & This study \\
\hline A. fuscipes & CMW10165 & Prunus persica & Zimbabwe & AY882966 & Coetzee et al. 2005 \\
\hline A. fuscipes & CMW2717 & Pinus elliottii & South Africa & AY882971 & Coetzee et al. 2005 \\
\hline A. fuscipes & CMW2740 & Pinus patula & South Africa & AY882970 & Coetzee et al. 2005 \\
\hline A. fuscipes & CMW3164 & Pelargonium asperum & La Reunion & AY882975 & Coetzee et al. 2005 \\
\hline A. fuscipes & CMW4871 & Widdringtonia whytei & Malawi & AY882976 & Coetzee et al. 2005 \\
\hline A. fuscipes & CMW4873 & Indigenous shrub & Malawi & AY882977 & Coetzee et al. 2005 \\
\hline A. fuscipes & CMW4874 & Araucaria cunninghamii & Zimbabwe & AY882967 & Coetzee et al. 2005 \\
\hline A. fuscipes & CMW4949 & Pinus elliottii & Tanzania & AY882978 & Coetzee et al. 2005 \\
\hline A. fuscipes & CMW4950 & Pinus strobes & Tanzania & AY882979 & Coetzee et al. 2005 \\
\hline A. fuscipes & CMW4953 & Pelargonium asperum & La reunion & AY882974 & Coetzee et al. 2005 \\
\hline A. fuscipes & CMW5844 & Pinus patula & Ethiopia & AY882969 & Coetzee et al. 2005 \\
\hline A. fuscipes & CMW5846 & Pinus patula & Ethiopia & AY882968 & Coetzee et al. 2005 \\
\hline A. fuscipes & CMW7184 & Cypress sp. & Kenya & AY882973 & Coetzee et al. 2005 \\
\hline A. fuscipes & CMW7187 & Camellia sinensis & Kenya & AY882972 & Coetzee et al. 2005 \\
\hline Armillaria sp. & CMW3173 & Tectona grandis & Zambia & AY882981 & Coetzee et al. 2005 \\
\hline Armillaria sp. & CMW4455 & Camellia sinensis & Zimbabwe & AY882985 & Coetzee et al. 2005 \\
\hline Armillaria sp. & CMW4456 & Brachystegia utilis & Zimbabwe & AY882984 & Coetzee et al. 2005 \\
\hline Armillaria sp. & CMW3152 & Unknown & Cameroon & AY882980 & Coetzee et al. 2005 \\
\hline Armillaria sp. & CMW10115 & Acacia albida & Zimbabwe & AY882983 & Coetzee et al. 2005 \\
\hline Armillaria sp. & CMW10116 & Newtonia buchananii & Zimbabwe & AY882982 & Coetzee et al. 2005 \\
\hline A. hinnulea & NZFS22376 & Unkown & New Zealand & EU734746 & Unpublished \\
\hline A. hinnulea & NZFS2394 & Unkown & New Zealand & EU734745 & Unpublished \\
\hline
\end{tabular}

B: Bokito; L: Loum; N: Ngat; P: Penja

* Strain in bold were collected during this study

white fungal mycelial mats beneath the bark (Fig. 1d, e, f). Gum exudation was only observed on support trees (Fig 1c). All isolates collected had the typical culture morphology of Armillaria species, such as the presence of abundant rhizomorph growth (Fig. 1g).
PCR amplification and sequencing of isolates yielded ITS amplicons ranging in size from 616 to $618 \mathrm{bp}$, and showing high (99\%) sequence identity with Armillaria isolates obtained previously from declining Theobroma cacao trees in Cameroon (Roux et al. 2012) and Tectona grandis in 
Table 2 Armillaria root rot incidence at three localities in Cameroon

\begin{tabular}{|c|c|c|c|c|c|c|c|}
\hline District & Plantation & $\begin{array}{l}\text { Farmer } \\
\text { obs. }^{1}\end{array}$ & $\begin{array}{l}\text { Armillara } \\
\text { Incidence }(\%)^{2}\end{array}$ & $\begin{array}{l}\text { Pepper vine } \\
\text { Mortality }(\%)^{3}\end{array}$ & Age (yrs.) & Associated crops & Previous land use \\
\hline \multirow[t]{13}{*}{ Tombel } & $\mathrm{T} 1$ & + & 3.4 & 27.2 & 9 & $\begin{array}{l}\text { Prunus africana, Persea } \\
\quad \text { americana, Cola acuminata }\end{array}$ & Coffea sp. \\
\hline & $\mathrm{T} 2$ & + & 30.0 & 87.7 & 3 & None & Coffea sp., T. cacao \\
\hline & $\mathrm{T} 3$ & + & 4.4 & 16 & 3 & $\begin{array}{l}\text { P. africana, P. americana, } \\
\text { C. acuminata }\end{array}$ & Coffea sp. \\
\hline & $\mathrm{T} 4$ & + & 17.2 & 21 & 15 & T. cacao, Dioscorea alata & Coffea sp., A. comosus \\
\hline & $\mathrm{T} 5$ & + & 1.3 & 1.2 & 7 & T. cacao & Native forest \\
\hline & T6 & + & 33.3 & 33.3 & 15 & Musa sp. & T. cacao \\
\hline & $\mathrm{T} 7$ & + & 28.6 & 56.8 & 7 & T. cacao, Musa sp. & T. cacao \\
\hline & $\mathrm{T} 8$ & - & - & 21 & 10 & T. cacao, D. alata & None \\
\hline & T9 & + & - & 22.2 & 5 & Ananas comosus, Musa sp. & Coffea sp. \\
\hline & $\mathrm{T} 10$ & - & - & 3.7 & 5 & Musa sp. & None \\
\hline & $\mathrm{T} 11$ & + & - & 67.6 & 10 & T. cacao, D. alata & T. cacao \\
\hline & T12 & - & - & 19.8 & 4 & T. cacao, Musa sp. & T. cacao, Coffea sp. \\
\hline & T13 & + & - & 4.9 & 8 & T. cacao, Musa sp. & Coffea sp. \\
\hline \multirow[t]{13}{*}{ Njombe- Penja } & N1 & + & 1.3 & 3.7 & 10 & Citrus sinensis, C. acuminata & T. cacao \\
\hline & $\mathrm{N} 2$ & + & 5.5 & 32.1 & 11 & None & T. cacao \\
\hline & N3 & + & 51.9 & 3.7 & 12 & None & Native forest, Musa sp. \\
\hline & N4 & + & - & 6.2 & 7 & None & T. cacao \\
\hline & N5 & + & - & 38.3 & 8 & Fruit trees & T. cacao \\
\hline & N6 & + & - & 6.2 & 25 & Musa sp., D. alata & C. acuminata, T. cacao \\
\hline & N7 & + & - & 9.9 & 10 & None & T. cacao \\
\hline & N8 & + & - & 18.5 & n.d. & Musa sp. & Forest trees \\
\hline & N9 & - & - & 8.6 & 8 & Musa sp. & C. papaya, A. comosus \\
\hline & N10 & + & - & 32.1 & 7 & C. acuminata, Musa sp. & T. cacao, C. acuminata \\
\hline & N11 & - & - & 6.2 & 3 & Carica papaya, A. comosus & Carica papaya \\
\hline & N12 & + & - & 2.5 & 6 & None & A. comosus \\
\hline & N13 & + & - & 8.6 & 6 & Musa sp., C. papaya & Musa sp. \\
\hline \multirow[t]{9}{*}{ Loum } & L1 & + & 4.5 & 18.5 & 4 & None & T. cacao \\
\hline & $\mathrm{L} 2$ & + & 64.9 & 28.4 & 6 & None & T. cacao \\
\hline & L3 & - & - & 7.4 & 16 & C. papaya & T. cacao \\
\hline & L4 & + & - & 4.9 & 5 & None & $\begin{array}{l}\text { Coffea sp., Manihot } \\
\text { esculenta }\end{array}$ \\
\hline & L5 & - & - & 9.8 & 10 & Musa sp. & Zea mays, Musa sp. \\
\hline & L6 & - & - & 39.5 & 17 & Musa sp., D. alata & Musa sp. \\
\hline & L7 & - & - & 2.5 & 8 & None & T. cacao \\
\hline & L8 & + & - & 18.5 & 8 & None & Coffea sp. \\
\hline & L9 & - & - & 29.6 & 11 & None & Musa sp. \\
\hline
\end{tabular}

${ }^{1} \pm$ presence or absence of the disease in the plantation according to the farmer

${ }^{2}$ Armillaria incidence based on transect data, $-=$ absence of Armillaria incidence within the transect

${ }^{3}$ Pepper vine mortality based on transect data

n.d. $=$ not determined

Zambia (Coetzee et al. 2005). In the ML based phylogram, the Armillaria isolates from Penja pepper fields grouped together, with strong bootstrap support (86\%), into a single phylogenetic clade, alongside the type A. camerunensis, as well as isolates associated with cacao root rot in Cameroon. This clade also included isolates from diverse host plants in Zambia and Zimbabwe (Fig. 2). The A. camerunensis clade is sister to another clade 
representing A. fuscipes, which is well supported by a strong bootstrap value of $99 \%$.

\section{Pathogenicity test}

The pathogenicity test showed no significant differences between treatments with regard to changes in plant height or leaf surface area nor for root and leaf dry weight at the end of the assay ( $P$-values $>0.2$ ), although on some uprooted pepper plants what seemed like necrotic root lesions were observed. However, a significant difference $(P=0.018, \mathrm{dl}=2, F=4.97$ ) was observed with regard to lesion length from the point of collar inoculation. Control plants had no lesion development, yet pepper seedlings infected by the pepper isolate had an average lesion size of $4.5 \mathrm{~mm}$ and those infected by the $S$. mombin isolate on average of $7.1 \mathrm{~mm}$ which was significantly different from the control. Certain plants presented yellowing, unfortunately, re-isolation efforts from wounds and necrotic roots were unsuccessful. Care has to be taken when interpreting these results. Pepper cuttings take several months before developing a root system and initially grow very slow. This, combined with the difficulty of Armillaria pathogenicity assays and the relatively short duration of the trial (4 months) may be the reason that no effects, other than the presence of lesions were observed.

\section{Discussion}

The ITS based phylogenic tree clearly shows how the Armillaria isolates from the Penja pepper fields grouped together into a single phylogenetic clade alongside the type A. camerunensis and isolates from Cameroon associated with cacao root rot. This clade is sister to another clade representing A. fuscipes (Fig. 2). This result is similar to those of Coetzee et al. (2005) who, relying on ITS and IGS1 based phylogenies, split A. fuscipes sensu lato (s. 1.), at the time considered a single specific entity, into two distinctive sister species. One species represented A. fuscipes sensu stricto (s. s.), and included isolates from South Africa, Zimbabwe, Kenya, and La Reunion. The second species, to which the Penja isolates appear to belong to, represented an undescribed species and included isolates from Cameroon, Zambia, and Zimbabwe. When Roux et al. (2012) used IGS1 phylogeny to identify Armillaria isolates associated with cacao root rot in Cameroon; they concluded that these isolates were conspecific with the unnamed second clade of A. fuscipes s. 1. This clade was later described as A. camerunensis by Koch et al. (2017). Unlike with the ITS as seen in this study, the phylogenetic tree based on IGS1 shows substantial sub-structuring in the A. camerunensis clade in Cameroon (Roux et al. 2012), which could be indicative of a high genetic diversity and possibly cryptic speciation in this species. Although two other
Armillaria species have in the past been reported from Cameroon, including. A. elegans and A. heimii (A. fuscipes) (Hennings 1895; Roux et al. 2012; Koch et al. 2017), DNA sequence studies have to date only recovered $A$. camerunensis in the country.

Many of the farms had previously grown, or were still growing, crops like cacao, Coffea spp. or fruit trees such as Citrus species, avocado (Persea americana), African plum (Dacryodes edulis) or cola nut (Cola nitida), next to or associated with the pepper (Table 2). Certain plots contained forest trees or remnants (stumps) thereof. Many of these are potential hosts for Armillaria (Roux and Coetzee 2016), which would explain the presence of the pathogen. Armillaria has been reported in Cameroon as early as 1892 (Hennings 1895) and has been found on cocoa in Cameroon, apparently as early as 1907 (Roux and Coetzee 2016), as well as in several other West African countries such as Sao Tomé, Togo and Ghana (Dade 1927; Rishbeth 1980; Roux and Coetzee 2016).

Since Armillaria spp. may survive decades in stumps and roots in the soils (Roux and Coetzee 2016), preparation of the terrain where a pepper plantation is to be established is key. Generally speaking, this disease spreads via root to root contact between infected and healthy plants, or through rhizomorphs or by mycelium present in the soil (Denman et al. 2000). Thus, manual removal of potentially infected plant material such as stumps and their root systems before establishment of the pepper plantation is recommended. Soil fumigation and soil inoculation with antagonistic fungi (e.g. Otieno et al. 2003) could further help to prepare a terrain. However, the efficacy of these methods is certainly not a hundred percent.

Once the disease is present, trenching is often used to prevent spread (Worrall 2004). This is only successful if the trench is dug well beyond the last affected trees. In one farmer's field in the Njombe-Penja district they tried this approach, which unfortunately did not seem to be very successful. This was either because the trench was dug too close to the area that was visibly affected or, since the affected area was on a slope, there was a downward movement of infectious propagules that was not stopped by the trench.

Many Penja pepper farmers use fungicides to control the disease cause by $A$. camerunensis, as this is the principal means they are comfortable with and knowledgeable about when it comes to pest and disease control. Unfortunately, chemical control is not very efficient in controlling Armillaria root rot (Thomidis and Exadaktylou 2012; Roux and Coetzee 2016).

Since the disease was more prevalent and more clearly visible on $S$. mombin than on pepper vines, we hypothesize that generally speaking the disease spreads through direct root contact from $S$. mombin to $P$. nigrum. If so, potentially using a different support tree not affected by Armillaria could solve the problem. Otherwise, support systems such as metal or 


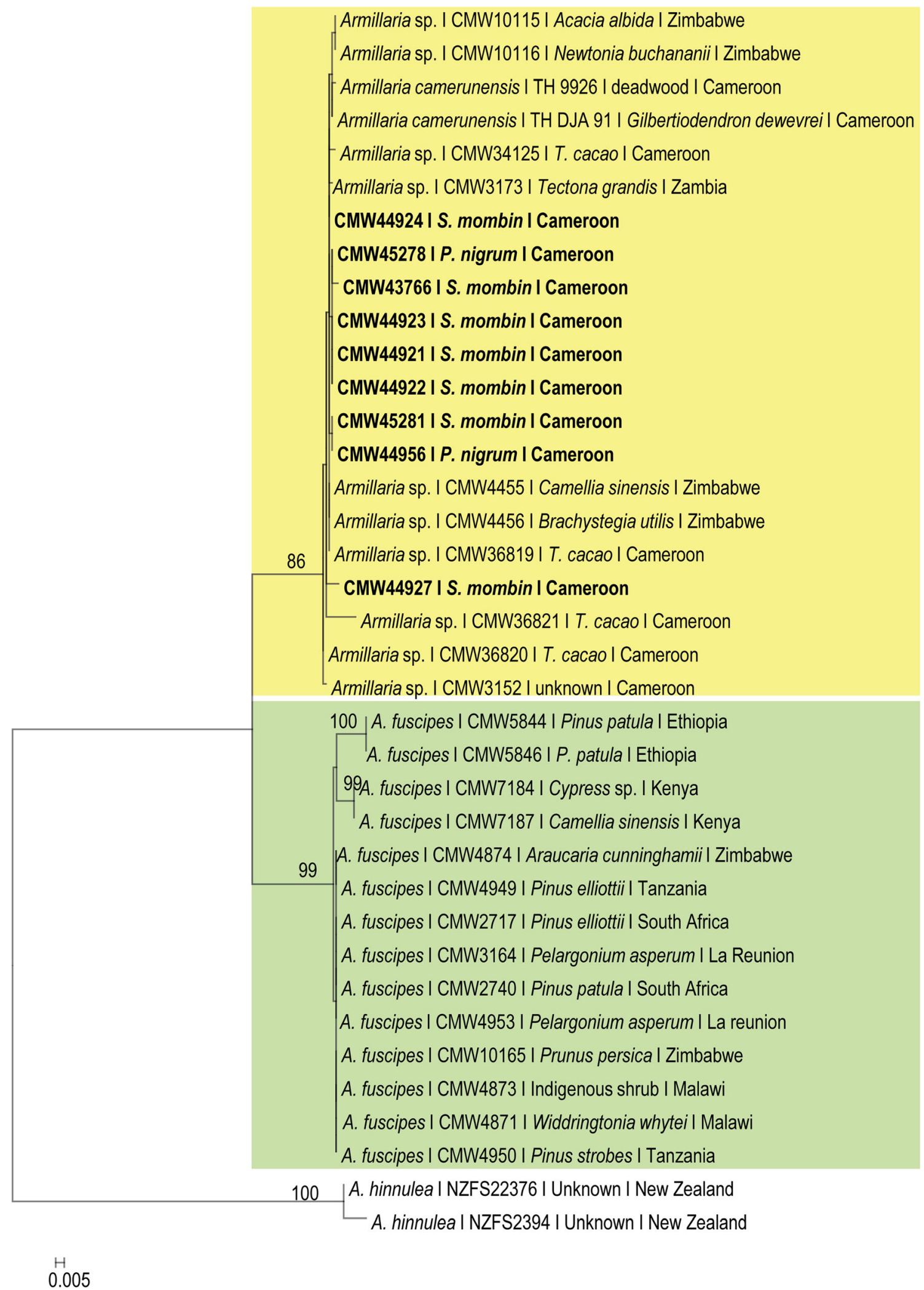

Fig. 2 Maximum Likelihood (ML) tree inferred from the ITS region showing the phylogenetic position of isolates obtained from Piper nigrum and Spondias mombin (in bold) from Cameroon. The tree was rooted with sequences of Armillaria hinnulea (KX618553 and KX618555). Bootstrap values $\geq 70 \%$ from 1000 replicates are displayed at the nodes 
concrete poles could be considered, although this would require an investment out of reach of most farmers. However, since a few pepper vines with clear Armillaria disease symptoms were observed attached to seemingly healthy support trees, this raises the question whether the disease can spread from $P$. nigrum to $S$. mombin. Ultimately, it seems that both species are potential hosts of this Armillaria sp.

Based on the results presented here, it is clear that Armillaria root rot, caused by A. camerunensis, is one of the main phytosanitary problems of Penja pepper cultivation, causing considerable economic impact. Familiarization of farmers with the causal agent and appropriate control methods are urgently needed to ensure sustained production of highly valued Penja Pepper. This is the first report of Armillaria root rot of S. mombin and P. nigrum globally.

Acknowledgements The authors would like to thank the Penja Pepper Geographical Indication Group (IGPP) producers, in particular René Claude Metomo Elogo (President of Association) and Emmanuel Nzenowo (Executive Secretary) for allowing database and field access. We also thank Fokou Rodrigue, Diazem Clovis, Tocké, Ngonga Florian, and Njonkam Ferdinand, agricultural technicians who assisted in the surveys. Funding and resources were provided by CIRAD, IRAD, the University of Pretoria and through the "Debt reduction-development contract (C2D) France Cameroon" Poivre de Penja project. The authors were free to publish any or all results originating from their work.

Author contributions Conceptualization: Petchayo TS, M Ndoumbé Nkeng, GM ten Hoopen; Methodology: Petchayo TS, JM Tchotet Tchoumi, M Ndoumbé Nkeng, GM ten Hoopen; Investigation: Petchayo TS, JM Tchotet Tchoumi, M. Mbenoun, GM ten Hoopen; Formal analysis: Petchayo TS, JM Tchotet Tchoumi, J Roux, M Mbenoun, M Ndoumbé Nkeng, GM ten Hoopen; Resources: J Roux, GM ten Hoopen; Funding acquisition: CV Mfegue, GM ten Hoopen; Project administration: S Nyassé; Supervision: J Nguefack, BAD Begoude, GM ten Hoopen; Writing original draft: Petchayo TS, GM ten Hoopen; Manuscript revision: Petchayo TS, GM ten Hoopen, M Mbenoun, JM Tchotet Tchoumi, J Roux. All authors read and approved the final manuscript.

\section{Compliance with ethical standards}

Conflict of interest On behalf of all authors, the corresponding author states that there is no conflict of interest.

\section{References}

Ahmad N, Fazal H, Abbasi H, Farooq S, Ali M, Ali Khan M (2012) Biological role of Piper nigrum L. (Black pepper): A review. Asian Pacific Journal of Tropical Biomedicine 2:S1945-S1953

Anandaraj M, Ramana KV, Sarma YR (1996) Sequential inoculation of Phytophthora capsici, Radopholus similis and Meloidogyne incognita in causing slow decline of black pepper. Indian Phytopathology 49:297-299

Cardoso DE, Albuquerque FC (1979) Podridão radicular e tombamento de plântulas de pimenta-do-reino em videira causada por Pythium splendens. Fitopatologia Brasileira 4:17-23

Coetzee MPA, Brenda D, Wingfield BP, Wingfield MJ (2005) Phylogenetic analyses of DNA sequences reveal species partitions amongst isolates of Armillaria from Africa. Mycological Research 109:1223-1234

Costa SS, Moreira GM, Pfenning LH (2017) Development of a PCR protocol for the identification and detection of Fusarium solani $\mathrm{f}$. sp. piperis from soil and roots of black pepper (Piper nigrum). Tropical Plant Pathology 42:55-59

Dade HA (1927) 'Collar crack of cacao': Armillaria mellea (Vahl.) Fr. Bulletin of Department of Agriculture Gold Coast. No. 5. 22p

Darriba D, Taboada GL, Doallo R, Posada D (2012) jModelTest 2: more models, new heuristics and parallel computing. Nature Methods 9: 772

Denman S, Coetzee MPA, Wingfield BD, Wingfield MJ, Crous PW (2000) Armillaria root rot. A new disease of cut- flower proteas in South Africa. Fynbos Research 33:1-6

Faostat (2017) http://www.fao.org/faostat/en/\#data (last Accessed 5/11/ 2019)

Ford KL, Henricot B, Baumgartner K, Bailey AM, Foster GD (2017) A faster inoculation assay for Armillaria using herbaceous plants. The Journal of Horticultural Science and Biotechnology 92:39-47

Hennings P (1895) Fungi camerunenses I. Botanische Jahrbücher für Systematik, Pflanzengeschichte und Pflanzengeographie 22:72-111

IPC (2017) http://www.ipcnet.org/index_n.php (last Accessed 5/11/ 2019)

Keuh TK (1990) Major diseases of black pepper and their management. Planter, Kuala Lumpur 66:59-69

Koch RA, Wilson AW, Séné O, Henkel TW, Aime C (2017) Resolved phylogeny and biogeography of the root pathogen Armillaria and its gasteroid relative, Guyanagaster. BMC Evolutionary Biology 17:33

Mbodiam BR (2019) Investir au Cameroun : agriculture, l'avenir du poivre de Penja en peril à cause des bioagresseurs qui détruisent les plantations. Consulted on August 23, 2019 [on line] URL https:// www.investiraucameroun.com

Meghwal M, Goswami TK (2012) Chemical composition nutritional, medical and functional properties of black pepper: a review. 1: 172. https://doi.org/10.4172/scientificreports. 172

Miller MA, Pfeiffer W, Schwartz T (2010) Creating the CIPRES science gateway for inference of large phylogenetic trees in Proceedings of the Gateway Computing Environments Workshop (GCE), 14 Nov. 2010, New Orleans, LA pp 1-8 https://dl.acm.org/citation. cfm?id=2016785 (last Accessed 13/11/2019)

Möller EM, Bahnweg G, Sandermann H, Geiger HH (1992) A simple and efficient protocol for isolation of high molecular weight DNA from filamentous fungi, fruit bodies, and infected plant tissues. Nucleic Acids Research 20:6115-6116

Otieno W, Jeger M, Termorshuizen A (2003) Effect of infesting soil with Trichoderma harzianum and amendment with coffee pulp on survival of Armillaria. Biological Control 26:293-301

Petchayo TS, Mfegue VC, Nguefack J, Tchotet TJM, Begoude BAD, Ducamp M, Djeugap JF, Ten Hoopen GM (2015) Penja pepper under threat in Cameroon! Poster Presented at the 6th Congress of European microbiologists (FEMS 2015) 7-11 June 2015 in Maastricht, the Netherlands

Ramana KV, Santhosh JE (2000) Nematode induced diseases of black pepper. In: Ravindran PN (ed) Black pepper, Piper nigrum. CRC Press, Amsterdam, pp 269-288

Ramana KV, Mohandas C, Balakrishnan R (1987) Role of plant parasitic nematodes in the slow wilt disease complex of black pepper (Piper nigrum L.) in Kerala. Indian Journl of Nematology 17:225-230

Ravindran PN (2000) Black pepper, Piper nigrum L. CRC Press, Amsterdam, p 526

Rishbeth J (1980) Armillaria on cacao in Sao Tome. Tropical Agriculture $57: 155-165$

Roux J, Coetzee MPA (2016) Armillaria root rot of Theobroma cacao. In: Bailey BA, Meinhardt LW (eds) Cacao diseases: a history of old enemies and new encounters. Springer International Publishing, Switzerland, pp 429-447. 
Roux J, Mbenoun M, Misse C, Coetzee MPA, Begoude DA, Wingfield MJ (2012) Molecular identification of Armillaria isolates associated with root-rot disease of cacao in Cameroon. 17th international Cocoa Research Congress (COPAL). 15-20 Oct. Yaoundé, Cameroon

Shahnazi S, Meon S, Vadamalai G, Ahmad K, Nejat N (2012) Morphological and molecular characterization of Fusarium spp. associated with yellowing disease of black pepper (Piper nigrum L.) in Malaysia. Journal of General Plant Pathology 78:160-169

Silvestro D, Michalak I (2012) raxmlGUI: a graphical front-end for RAxML. Organisms, Diversity and Evolution 12:335-337

Stamatakis A (2006) RAxML-VI-HPC: maximum likelihood-based phylogenetic analyses with thousands of taxa and mixed models. Bioinformatics 22:2688-2690

Tchotet Tchoumi JM, Coetzee MPA, Vivas M, Rajchenberg M, Roux J (2017) Wood-rotting basidiomycetes associated with declining native trees in timber-harvesting compartments of the garden route National Park of South Africa. Austral Ecology 42:947-963
Thomidis T, Exadaktylou E (2012) Effectiveness of cyproconazole to control Armillaria root rot of apple, walnut and kiwifruit. Crop Protection 36:49-51

Truong NV, Burgess LW, Liew ECY (2008) Prevalence and aetiology of Phytophthora foot rot of black pepper in Vietnam. Australasian Plant Pathology 37:431

White TJ, Bruns T, Lee S, Taylor J (1990) Amplification and direct sequencing of fungal ribosomal RNA genes for phylogenetics. In: Innis MA, Gelfand DH, Sninsky JJ, White TJ (eds) PCR protocols: a guide to methods and applications. Academic Press, New York, pp 315-322

Worrall JJ (1991) Media for selective isolation of hymenomycetes. Mycologia 83:296-202

Worrall JJ (2004) Armillaria root disease. The Plant Health Instructor. American Phytopathological Society. https://doi.org/10.1094/PHI-I2004-0706-01

Publisher's note Springer Nature remains neutral with regard to jurisdictional claims in published maps and institutional affiliations. 